\title{
Pengaruh Modal Psikologis terhadap Persepsi Resiliensi Organisasi dalam Menghadapi Pandemi COVID-19
}

\author{
MUHAMMAD FARRAS SAID \& DIMAS ARYO WICAKSONO* \\ Departemen Psikologi Industri dan Organisasi, Fakultas Psikologi Universitas Airlangga
}

\begin{abstract}
ABSTRAK
Penelitian ini bertujuan untuk mengetahui pengaruh modal psikologis terhadap persepsi resiliensi organisasi dalam menghadapi pandemi COVID-19. Penelitian sebelumnya menemukan bahwa masingmasing komponen modal psikologis mempengaruhi aktivasi mekanisme coping individu, yang sebagai konsekuensinya membangun dan meningkatkan resiliensi organisasi. Sampel penelitian merupakan karyawan aktif yang tempat bekerjanya pernah atau sedang terdampak peraturan Pembatasan Sosial Berskala Besar (PSBB). Terkumpul sejumlah 332 subjek yang memenuhi kriteria tersebut. penulis menggunakan alat ukur Psychological Capital Questionnaire (PCQ) untuk mengukur modal psikologis dan alat ukur Benchmark Resilience Tool-13B (BRT-13B) untuk mengukur persepsi resiliensi organisasi. Uji reliabilitas menggunakan McDonald's $\omega$. Hasil reliabilitas alat ukur PCQ adalah 0,918 dan untuk BRT-13B adalah 0,902. Analisis data menggunakan regresi linear sederhana dengan menggunakan Jamovi 1.2.27.0 for windows. Hasil pada penelitian ini adalah modal psikologis berpengaruh secara signifikan terhadap persepsi resiliensi organisasi $(p<0,001)$.
\end{abstract}

Kata kunci: COVID-19, modal psikologis, resiliensi organisasi

\begin{abstract}
This study aims to determine the effect of psychological capital towards percieved organizational resilience in the face of the COVID-19 pandemic. Previous studies found that each component of psychological capital influences the activation of individual coping mechanisms, which as a consequence builds and increases organizational resilience. The research sample is active employees whose workplaces have been or are being affected by the Large-Scale Social Restrictions (PSBB) regulations. There were 332 subjects who met these criteria. This research used the Psychological Capital Questionnaire (PCQ) to measure psychological capital and the Benchmark Resilience Tool-13B (BRT13B) to measure perceived organizational resilience. Reliability was conducted using McDonald's $\omega$. The result of the reliability of the PCQ is 0.918 and for BRT-13B is 0.902 . The data was analyzed with simple linear regression using Jamovi 1.2.27.0 for windows. The result in this study is that psychological capital has a significant effect on perceived organizational resilience $(\mathrm{p}<0.001)$.
\end{abstract}

Keywords: COVID-19, perceived organizational resilience, psychological capital 


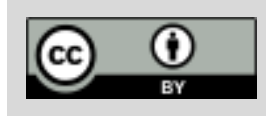

Naskah ini merupakan naskah dengan akses terbuka dibawah ketentuan the Creative Common Attribution License (CC-BY-4.0) (http://creativecommons.org/licenses/by/4.0), sehingga penggunaan, distribusi, reproduksi dalam media apapun atas artikel ini tidak dibatasi, selama sumber aslinya disitir dengan baik.

\section{P E N D A H U L U A N}

Tahun 2020 memberikan sebuah tantangannya tersendiri dengan pandemi COVID-19 yang melanda di hampir semua negara di dunia. Sejak tanggal 11 Maret 2020, wabah COVID-19 dinyatakan sebagai pandemi oleh World Health Organization (WHO) (World Health Organization, 2020). Karena deteksi COVID-19 sulit untuk dilakukan selain melalui swab test (tes usap) dan rapid test (tes cepat), WHO merekomendasikan individu untuk menjaga jarak fisik, menjaga kebersihan tangan dengan rajin mencuci tangan, menghindari keramaian, menghindari tempat tertutup yang memiliki ventilasi yang buruk, menggunakan masker kain 3 lapis jika berada di tempat publik yang tidak memungkinkan atau sulit untuk menjaga jarak fisik, memastikan ventilasi udara yang baik untuk menghindari penyebaran droplet melalui transmisi aerosol, dan pembersihan lingkungan secara rutin menggunakan disinfektan untuk membunuh virus COVID-19 (World Health Organization, 2020).

Dengan rekomendasi WHO tersebut, pemerintah menerbitkan Peraturan Pemerintah Republik Indonesia no. 21 Tahun 2020 yang membahas tentang kebijakan Pembatasan Sosial Berskala Besar (PSBB) untuk mencegah penyebaran COVID-19. Mulai tanggal 10 April 2020 hingga pertengahan bulan Juni 2020 banyak tempat bisnis dan tempat publik (rumah ibadah, museum, lapangan olahraga dalam ruangan) di DKI Jakarta yang ditutup sebagian atau sepenuhnya. Pembatasan aktivitas tersebut, terutama aktivitas bisnis, menyebabkan kondisi pertumbuhan ekonomi di Indonesia melambat. Dikutip dari kanal berita daring CNN, Menteri Keuangan Sri Mulyani menjelaskan bahwa kebijakan PSBB menyebabkan perlambatan ekonomi lebih dalam dari kuartal I, yaitu 2,9 persen. Sri Mulyani menyatakan bahwa kemungkinan pertumbuhan ekonomi bisa lebih melambat lagi pada kuartal II setelah penerapan kebijakan PSBB (Sri Mulyani Sebut Kebijakan PSBB 'Pukul' Ekonomi RI, 2020).Hal itu terbukti terjadi pada kuartal II, ketika Badan Pusat Statistik (BPS), dikutip dari kanal berita daring tirto.id, mencatat pertumbuhan ekonomi pada kuartal II tahun 2020 mengalami kontraksi sebesar 5,32 persen year-on-year (Thomas, 2020). Kontraksi tersebut lebih dalam dari perkiraan Kementrian Keuangan di kisaran minus 3,8 persen. Secara quarter-to-quarter (qtoq), pertumbuhan ekonomi Indonesia tahun 2020 terkontraksi atau minus 4,19 persen. Kontraksi ini merupakan kontraksi pertama sejak krisis pada tahun 1999, ketika Indonesia mengalami kontraksi sebesar 6,13 persen.

Dampak dari Covid-19 ini bukan hanya terhadap pengurangan permintaan terhadap barang-barang tertentu saja. Beberapa barang, seperti masker, alat perlindungan diri, dan hand sanitizer sempat mengalami permintaan yang jauh melebihi kemampuan produksi yang dimiliki oleh perusahaan pembuat barang-barang tersebut. Hal ini sempat berusaha ditangani dengan memberikan himbauan pada masyarakat untuk tidak menggunakan masker apabila tidak mengalami gejala Covid-19, sebagai usaha untuk menjaga ketersediaan masker bagi tenaga kesehatan, dan untuk menghindari penggunaan APD apabila tidak perlu. Pemerintah juga mendorong pelaku usaha seperti pelaku usaha konveksi, baik skala besar maupun skala rumahan, untuk memproduksi masker kain agar dapat mengulur waktu bagi produsen masker sekali pakai untuk berusaha meningkatkan kapasitas produksinya (Masker Menjadi Peluang Usaha di Masa Pandemi COVID-19, 2020).

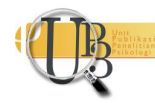


Dengan situasi pandemi yang menyebabkan krisis ekonomi seperti saat ini, komunitas-komunitas masyarakat di Indonesia akan mengandalkan organisasi untuk bertahan hidup dan memulihkan diri dari krisis yang sedang dihadapi. Dalam hal ini, resiliensi komunitas dan resiliensi organisasi memang memiliki hubungan secara intrinsik, yang mana organisasi yang resilien dapat membantu meningkatkan resiliensi komunitas dalam menghadapi bencana dan memulihkan komunitas pasca menghadapi bencana (McManus, 2008). Selain itu, kenaikan permintaan yang mendadak dan tinggi ini menjadikan perusahaan harus resilien, karena, meskipun situasinya menguntungkan, kenaikan permintaan yang tinggi secara tiba-tiba akan sulit untuk diimbangi apabila resiliensi organisasi perusahaan buruk.

Selain itu, organisasi yang resilien juga lebih unggul dalam situasi business as usual. meskipun dalam situasi yang normal (Vargo \& Stephenson, 2010 dalam Lee dkk., 2013). Vargo \& Stephenson (2010, dalam Lee dkk., 2013) membahas tentang keunggulan kompetitif dan kemiripannya dan hubungannya dengan resiliensi organisasi. Sebagai contoh, situation awareness sebuah organisasi, kemampuan suatu organisasi dalam menginterpretasi informasi tentang lingkungan bisnisnya dan memahami maksud dari informasi tersebut untuk organisasi pada masa kini hingga masa depan, sangat mirip dengan salah satu keunggulan kompetitif yaitu kemampuan untuk mengetahui saingan dan lingkungan organisasi. Atas dasar tersebut, Lee dkk., (2013) menyatakan bahwa organisasi yang resilien bisa menjadi lebih kompetitif dalam situasi biasa.

\section{Persepsi Resiliensi Organisasi}

Resiliensi organisasi memiliki berbagai definisi yang cukup berbeda. Secara garis besar, pandangan para ahli tentang makna dari resiliensi terbagi dua, yaitu resiliensi sebagai sebuah sifat yang dibutuhkan individu untuk bertahan, dan resiliensi sebagai suatu cara untuk berkembang (Harms, Brady, Wood, \& Silard, 2018). Dalam konteks organisasi, beberapa ahli mendefinisikan bahwa resiliensi adalah sesuatu yang bersifat pasif, artinya resiliensi hanya dipandang sebagai kemampuan untuk bertahan dan kembali ke normal (Wildavsky, 1988 dalam Somers, 2009). Pandangan ini memaknai resiliensi organisasi hanya sebatas reaksi terhadap situasi krisis (Somers, 2009).

Di sisi lain, beberapa ahli memaknai resiliensi organisasi sebagai sesuatu yang aktif, artinya resiliensi adalah "suatu usaha yang disengaja untuk menjadi lebih baik dalam menghadapi kejadian yang tidak terduga" (Lovins \& Lovins, 1982 dikutip oleh Wildavsky, 1988:98, dalam Somers, 2009). Dalam pandangan ini, resiliensi tidak lagi dipandang sebagai sekedar reaksi terhadap suatu situasi semata, tetapi dipandang sebagai sesuatu yang bisa dibangun, dipersiapkan, dan direncanakan, untuk memaksimalkan kapasitas organisasi untuk menghadapi krisis (Lengnick-Hall \& Beck, 2005; Wildavsky, 1988 dalam Somers, 2009; Mallak, 1998; Gibson \& Tarrant, 2010). Penelitian ini memandang resiliensi organisasi sebagai sesuatu yang bersifat aktif, artinya bahwa resiliensi organisasi dapat direncanakan dan dapat dibangun.

Selanjutnya, McManus (2008) dari hasil studi kasusnya pada 10 organisasi di Selandia Baru, mendefinisikan resiliensi sebagai fungsi dari situation awareness, pengelolaan kerentanan, dan kapasitas adaptif dari suatu organisasi dalam sistem yang kompleks, dinamis, dan saling berkaitan. Namun, McManus (2008) menyatakan bahwa definisi tersebut hanya berlaku pada organisasi yang diobservasi untuk studi kasusnya, dan harus diulas kembali agar bisa diterapkan dalam skala yang lebih luas (Stephenson, 2010).

Hal tersebut kemudian dijawab oleh penelitian Stephenson (2010) yang mengembangkan model resiliensi organisasi yang didasarkan dari model milik McManus (2008) yang berpendapat bahwa terdapat 2 faktor besar yang mempengaruhi resiliensi organisasi yang memiliki 13 indikator. Faktor

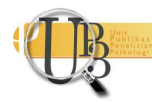


tersebut merupakan faktor sosial dan perilaku yang dinamai sebagai faktor kapasitas adaptif dan perencanaan (Stephenson, 2010). Stephenson (2010) berpendapat bahwa untuk meningkatkan resiliensi dalam organisasi, organisasi harus berusaha untuk menemukan keseimbangan antara meningkatkan kapasitas adaptif dan memformalisasikan perencanaan. Stephenson (2010) juga berpendapat bahwa selain mengatasi kelemahan, organisasi harus memanfaatkan kelebihan mereka untuk menjaga dan meningkatkan resiliensinya.

Pengukuran resiliensi organisasi yang dilakukan oleh Stephenson (2010) merupakan pengukuran yang mengungkap penilaian individu terhadap resiliensi organisasinya. Indikator-indikator resiliensi organisasi yang disusun oleh Stephenson (2010) mengukur persepsi individual terkait resiliensi organisasinya, seperti kepemimpinan, pengambilan keputusan, inovasi dan kreativitas, dan lainnya. Hasil pengukuran yang akan dihasilkan dari alat ukur milik Stephenson (2010) akan menghasilkan penilaian individu terkait resiliensi organisasinya, yang didasarkan dari pengalaman dan pengetahuan individu terkait apa saja yang dilakukan oleh organisasinya. Hal ini dapat memberikan informasi bagi organisasi terkait realita situasi resileinsi organisasinya saat ini (Stephenson, 2010).

\section{Modal Psikologis}

Modal psikologis, dalam penelitian ini, didefinisikan sebagai keadaan psikologis positif individu yang ditandai dengan adanya rasa kepercayaan diri (self-efficacy) untuk mengerjakan dan mengerahkan usaha yang dibutuhkan dalam menyelesaikan tugas-tugas yang menantang, membentuk atribusi positif (optimism) terhadap kesuksesan di masa sekarang maupun di masa yang akan datang, gigih dalam usahanya untuk mencapai tujuan dan mengarahkan kembali langkah-langkah yang dilakukannya untuk mencapai tujuan bila perlu (hope), dan mampu bertahan dan bangkit kembali bahkan lebih baik dari sebelumnya apabila menghadapi permasalahan dan kesulitan (resilience) (Luthans, Youssef, \& Avolio, 2007).

\section{Modal Psikologis dan Persepsi Resiliensi Organisasi}

Resiliensi organisasi tumbuh apabila organisasi memiliki sumber daya yang cukup. McManus dkk. (2007, dalam Fang dkk., 2020) menjelaskan bahwa posisi finansial suatu organisasi dapat menjadi kunci penentu bagi keberhasilan organisasi dalam menghadapi suatu krisis dan mengerahkan sumber daya yang diperlukan untuk menghadapi krisis tersebut. Salah satu sumber daya yang harus dikerahkan adalah sumber daya manusia, yang harus diperhatikan juga kesejahteraannya (Walker dkk., 2014 dalam Fang dkk., 2020).

Selain itu, resiliensi organisasi dapat tumbuh dari modal psikologis yang diaktifkan oleh coping mechanism manajer perusahaan (Fang, Prayag, Ozanne, \& de Vries, 2020). Masing-masing komponen dari modal psikologis, yaitu efikasi diri, harapan, optimisme, dan resiliensi psikologis diaktifkan melalui problem-focused dan emotion-focused coping mechanism (Fang, Prayag, Ozanne, \& de Vries, 2020). Selanjutnya, masing-masing coping mechanism tersebut mempengaruhi tinggi rendahnya masingmasing komponen modal psikologis yang ditunjukkan, dan pada akhirnya mempengaruhi bagaimana manajer mengarahkan organisasinya dalam menghadapi krisis, yang dalam prosesnya menumbuhkan resiliensi organisasi (Fang, Prayag, Ozanne, \& de Vries, 2020). Sebagai contoh, komponen efikasi diri dalam modal psikologis dapat mempengaruhi kreativitas dan inovasi individu dalam mencari cara untuk menyelesaikan masalah, yang mana hal tersebut merupakan salah satu komponen resiliensi organisasi menurut Stephenson (2010).

Norman, Luthans, dan Luthans (2005, dalam Shani, 2020) mengusulkan bahwa melalui contagion effect, seorang manajer atau pemimpin mampu "menularkan" komponen-komponen modal psikologisnya

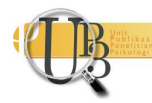


kepada individu-individu lain yang berada di organisasi. Dalam usulannya, Norman, Luthans, dan Luthans (2005, dalam Shani, 2020) mengusulkan bahwa resiliensi dari pemimpin dan pengikut dapat bergabung untuk mempengaruhi resiliensi organisasi secara keseluruhan.

Teori lainnya tentang bagaimana terbentuknya hubungan antara modal psikologis dengan resiliensi organisasi bisa dijelaskan melalui social learning theory (Bai, Lin \& Liu, 2019; Bandura, 2008 dalam Shani, 2020). Berdasarkan social learning theory, manajer adalah model bagi bawahannya. Manajer yang menunjukkan bahwa dia memiliki modal psikologis yang bagus dapat menginspirasi bawahannya melalui perilakunya Ketika mengalami suatu kesulitan, perilaku manajer tersebut akan dicontoh oleh para subordinatnya, yang dapat mempengaruhi resiliensi organisasinya (Luthans, Youssef, \& Avolio, 2007).

Shani (2020) menggunakan teori contagion effect dan social learning theory sebagai landasan untuk meneliti pengaruh dari modal psikologis pada resiliensi organisasi, dan menemukan bahwa modal psikologis tidak memiliki korelasi yang signifikan pada resiliensi organisasi. Penelitian tersebut menemukan bahwa modal psikologis memiliki korelasi yang positif dan signifikan dengan inovasi organisasi. Dalam pembahasannya, Shani (2020) menjelaskan bahwa meskipun studi literatur dari Norman, Luthans, dan Luthans (2005, dalam Shani, 2020) menunjukkan kemungkinan korelasi yang signifikan antara modal psikologis dan resiliensi organisasi, hasil temuan penelitiannya menunjukan yang sebaliknya. Shani (2020) memperkirakan bahwa hal tersebut disebabkan oleh kesamaan dari modal psikologis yang dimiliki oleh para partisipan (kepala sekolah, dalam konteks penelitiannya). Kemungkinan besar homogenitas dari respons masing-masing partisipan terhadap kuesioner yang diberikan tersebut lah yang menyebabkan sulitnya secara statistik untuk menemukan hubungan dari modal psikologis manajer dan resiliensi organisasi.

Terdapat kesenjangan di sini, antara das solen yaitu modal psikologis dapat mempengaruhi resiliensi organisasi (Norman, Luthans, dan Luthans, 2005, dalam Shani, 2020) dan das sein menurut Shani (2020) yaitu modal psikologis tidak memiliki hubungan yang signifikan dengan resiliensi organisasi. Selain itu, penulis juga menemukan kesulitan untuk mencari penelitian yang meneliti tentang hubungan modal psikologis dengan resiliensi organisasi yang dapat digunakan penulis sebagai referensi, yang menunjukkan kurangnya penelitian yang mengeksplor hubungan antara modal psikologis dengan resiliensi organisasi. Penelitian ini berusaha untuk menambahkan penelitian yang mengungkap pengaruh dari modal psikologis dengan resiliensi organisasi, dengan harapan bahwa penelitian ini bisa menambah sumber bagi individu-individu yang membutuhkan penelitian yang sejenis.

Dari penjelasan masalah tersebut, peneliti memutuskan untuk melakukan penelitian untuk menemukan apakah terdapat pengaruh dari variabel modal psikologis terhadap persepsi resiliensi organisasi. Sementara, tujuan penelitian ini adalah untuk mengetahui dan menganalisis pengaruh dari modal psikologis terhadap persepsi resiliensi organisasi dalam menghadapi krisis ekonomi yang disebabkan oleh COVID-19. Sementara untuk hipotesis kerja pada penelitian ini adalah bahwa modal psikologis berpengaruh terhadap persepsi resiliensi organisasi dalam menghadapi pandemi COVID-19

\section{Desain Penelitian}

\section{E T O D E}

Pada penelitian kali ini penulis menggunakan pendekatan kuantitatif dengan desain penelitian survei cross-sectional (Neuman, 2014). Penelitian kuantitatif artinya penulis menggunakan data-data dalam

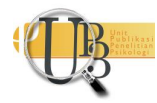


bentuk angka yang nantinya diolah menggunakan metode statistik untuk menjelaskan suatu fenomena (Neuman, 2014). Penelitian cross-sectional artinya penulis mengumpulkan data hanya pada satu waktu tertentu dari populasi yang ditentukan. Untuk mengumpulkan data, penulis menggunakan kuesioner tertulis yang isinya sama yang disebarkan pada sekelompok orang yang sesuai kriteria. Menurut Neuman (2014), penelitian yang menggunakan cara pengumpulan data seperti ini bisa disebut sebagai penelitian survei.

Penelitian ini merupakan penelitian eksplanatif, sehingga penelitian ini berusaha untuk menerangkan dan menguji hipotesis dari variabel-variabel penelitian. Penelitian ini berfokus untuk menguji pengaruh antara kedua variabel, yaitu variabel modal psikologis (independen) dan variabel resiliensi organisasi (dependen).

\section{Partisipan}

Populasi adalah konsep abstrak dari sebuah kelompok besar yang di dalamnya terdapat banyak kasus, dan nantinya penulis akan mengambil sampel dari kelompok tersebut (Neuman, 2014). Sementara, sampel adalah sebuah unit analisis yang dipilih untuk mewakili populasi (Neuman, 2014). Dalam penelitian ini, kriteria populasi yang diambil sampelnya adalah karyawan yang tempat bekerjanya pernah atau sedang terdampak peraturan PSBB.

Peneliti tidak membatasi status pekerjaan karyawan karena terlepas dari status pekerjaannya, setiap individu di dalam organisasi sedikit atau banyak akan berpengaruh terhadap resiliensi organisasi secara keseluruhan (Stephenson, 2010). Peneliti menetapkan bahwa tempat kerja karyawan tersebut harus pernah atau sedang terdampak peraturan PSBB untuk memastikan bahwa tempat kerjanya sedang atau telah menghadapi kesulitan yang disebabkan oleh COVID-19.

Penggunaan pembatasan subjek berdasarkan pada pernah atau tidaknya tempat bekerjanya terdampak peraturan PSBB adalah karena peraturan PSBB tersebut yang mengawali terjadinya krisis ini. Meskipun peraturan mengenai PSBB ini dibentuk oleh pemerintah pusat, namun untuk penerapannya bisa berbeda masing-masing sesuai dengan kebijakan pemerintah daerahnya. Hal ini menimbulkan perbedaan dampak yang berbeda, karena beberapa tempat seperti DKI Jakarta sempat memberlakukan PSBB total ketika kota yang bersebelahan, seperti Kota Depok tidak menerapkan PSBB total. Kebijakankebijakan PSBB yang bervariasi di masing-masing daerah berimbas pada beberapa bisnis, seperti bisnis rumah makan, yang cukup bergantung pada kedatangan konsumen ke restorannya. Oleh karena itu, dengan pertimbangan bahwa PSBB bukan peraturan yang seragam di berbagai daerah, melainkan berbeda-beda di setiap daerah, hal tersebut menjadikannya kriteria pembatas bagi populasi penelitian ini.

Teknik sampling untuk penelitian ini menggunakan teknik non-probability sampling dengan metode accidental sampling. Teknik non-probabiltiy sampling adalah teknik yang memberikan peluang atau kesempatan yang tidak sama kepada seluruh populasi untuk dipilih sebagai sampel (Neuman, 2014). Metode accidental sampling adalah metode penentuan sampel yang artinya sampel ditentukan berdasarkan kebetulan, yaitu bagi siapa saja yang memenuhi kriteria dan kebetulan melihat kuesioner yang disebarkan oleh peneliti (Neuman, 2014). Untuk memperoleh sampel, peneliti menyebarkan kuesioner secara daring dengan menyertakan kriteria yang sudah ditetapkan, dan bagi siapapun yang melihat kuesioner yang dibagikan, memenuhi kriteria tersebut, dan bersedia untuk mengisinya akan menjadi sampel.

Untuk menentukan jumlah sampel, peneliti menggunakan bantuan perangkat lunak G.Power 3.1.9.7. Peneliti menggunakan a priori power analysis untuk menentukan minimal sampel yang harus didapatkan untuk menghasilkan effect size (Cohen's $f^{2}$ ) sebesar 0,15, $\alpha$ error probability 0,05 dan

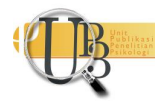


statistical power $(1-\beta)=0,95$, dengan jumlah prediktor yang diuji sebanyak 1 , dan jumlah total prediktor sebanyak 2. Hasil dari analisis tersebut menghasilkan minimal sampel yang dibutuhkan sebanyak $\mathrm{N}=89$. Berdasarkan hasil analisis tersebut, dapat disimpulkan bahwa peneliti minimal mendapatkan sampel sebanyak 89.

\section{Pengukuran}

Untuk mengumpulkan data yang dibutuhkan, instrumen pengumpulan data berupa survei yang berbentuk kuesioner untuk mendapatkan data penelitian. Kuesioner yang digunakan adalah kuesioner dalam jaringan (daring), menggunakan bantuan platform Google Form. Tautan survei berisi undangan partisipasi, informed consent, dan kuesioner yang akan diisi oleh partisipan dan disebarkan melalui media sosial, aplikasi pesan instan, dan cara-cara lain yang dirasa bisa membantu penyebaran tautan tersebut.

Terdapat dua alat ukur yang digunakan dalam penelitian ini, yaitu alat ukur Psychological Capital Questionnaire (PCQ) yang disusun oleh Luthans, Youssef, dan Avolio (2007) yang diterjemahkan oleh Purwasono (2016) untuk keperluan penelitian tugas akhir untuk mengukur variabel modal psikologis dan Benchmark Resilience Tool 13-B (BRT-13B) milik Whitman dkk. (2013) yang merupakan versi pendek dari skala Benchmark Resilience Tool (BRT-53) milik Stephenson (2010) untuk mengukur variabel persepsi resiliensi organisasi.

Alat ukur PCQ terdiri dari 4 dimensi, yaitu efikasi diri, optimisme, harapan, dan resiliensi, yang masingmasing diwakili oleh 6 aitem, sehingga terdapat total aitem sebanyak 24. Skala yang digunakan adalah skala likert dengan rentang pilihan dari 1 (sangat tidak setuju) hingga 6 (sangat setuju). Skor untuk skala ini diberikan sesuai dengan rentang pilihan tersebut yaitu 1 terendah dan 6 tertinggi, kecuali untuk aitem unfavorable yang dibalik menjadi 6 terendah dan 1 tertinggi. Reliabilitas skala dihitung dengan menggunakan McDonald's $\omega$ dengan bantuan perangkat lunak Jamovi for Windows 1.2.27. dan menghasilkan koefisien sebesar 0,918, yang menandakan bahwa alat ukur PCQ memiliki reliabilitas yang tinggi.

Alat ukur BRT-13B terdiri dari 13 aitem yang mewakili 2 dimensi, yaitu kapasitas adaptif dan perencanaan. Dimensi kapasitas adaptif terdiri dari 8 indikator, sementara dimensi perencanaan terdiri dari 5 indikator. Sehingga, terdapat 13 aitem yang mewakili 13 indikator. Artinya, 1 indikator diwakili oleh 1 aitem. Instrumen BRT-13B menggunakan skala likert dengan rentang pilihan dari 1 (sangat tidak setuju) sampai 6 (sangat setuju), dengan aturan penilaian yang sama seperti alat ukur PCQ. Reliabilitas skala dihitung dengan menggunakan McDonald's $\omega$ dengan bantuan perangkat lunak Jamovi for Windows 1.2.27. dan menghasilkan koefisien sebesar 0.902, yang menandakan bahwa alat ukur BRT13B memiliki reliabilitas yang tinggi.

Skor masing-masing skala untuk masing-masing individu didapatkan dengan cara menjumlahkan total jawabannya sesuai dengan pilihannya. Tidak terdapat cara penghitungan yang khusus, hanya dijumlahkan per individu saja.

\section{Analisis Data}

Untuk menguji hipotesis penelitian, penulis menggunakan teknik analisis regresi linear sederhana. Hal ini dikarenakan tujuan penelitian adalah untuk mengetahui pengaruh modal psikologis terhadap resiliensi organisasi, dan hanya terdapat dua variabel yaitu variabel modal psikologis dan resiliensi organisasi (Navarro \& Foxcroft, 2019). Sebelum melakukan uji regresi, perlu dilakukan uji asumsi. Uji

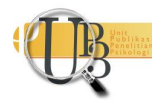


asumsi yang harus dilakukan adalah uji homoskedastisitas, normalitas, dan linearitas. Seluruh analisis data untuk penelitian ini dilakukan menggunakan perangkat lunak Jamovi for Windows 1.2.27.

Uji Asumsi

Sebelum melakukan analisis regresi linear sederhana, terdapat beberapa asumsi yang harus terpenuhi. Untuk memastikan bahwa asumsi-asumsi tersebut terpenuhi, penulis melakukan uji asumsi dengan bantuan perangkat lunak jamovi 1.2.27 for Windows.

Tabel 1 menunjukkan hasil uji normalitas. Agar data bisa dianggap normal, angka skewness dan kurtosis harus mendekati angka 0, dengan angka -2 hingga 2 merupakan batas maksimum agar tetap dianggap normal (Navarro \& Foxcroft, 2019). Pada tabel 1, terlihat bahwa skewness dan kurtosis masing-masing variabel berada di antara 1 hingga -1 , sehingga asumsi normalitas terpenuhi.

Tabel 1. Hasil Uji Normalitas

\begin{tabular}{lll}
\hline Variabel & Skewness & Kurtosis \\
\hline Modal Psikologis & $-0,429$ & 0,473 \\
\hline Resiliensi Organisasi & $-0,431$ & 0,066 \\
\hline
\end{tabular}

Asumsi homoskedastisitas diuji menggunakan uji Levene. Interpretasi hasil uji Levene adalah, jika signifikansi (p) lebih dari 0,05, maka asumsi homoskedastisitas terpenuhi. Setelah dilakukan uji Levene, luaran data menunjukkan bahwa $\mathrm{p}=0,191$. Artinya, $\mathrm{p}>0,05$, yang berarti bahwa asumsi homoskedastisitas terpenuhi.

\section{HAS IL PENELITIAN}

Untuk menguji hipotesis penelitian, penulis berhasil mendapatkan 332 partisipan. Partisipan mayoritas berusia 25-34 tahun (30,1 persen), berjenis kelamin perempuan (57,2 persen), memiliki latar belakang pendidikan D4/S1/Sederajat (65,1 persen), bekerja di sektor jasa keuangan (24,7 persen), dan memiliki jabatan sebagai staf $(54,8$ persen $)$.

Uji hipotesis menggunakan analisis regresi linear sederhana. Setelah dilakukan analisis regresi linear sederhana, dapat diketahui bahwa nilai dari variabel modal psikologis tepat untuk memprediksi nilai dari variabel persepsi resiliensi organisasi $\left(\mathrm{F}(1,330)=166 ; \mathrm{p}<0,001 ; R^{2}=0.335\right)$ dengan koefisien determinasi sebesar 33,5\%. Hal ini menunjukkan bahwa variabel modal psikologis dapat menjelaskan perubahan dalam variabel persepsi resiliensi organisasi sebesar 33,5\%. Sementara, 66,5\% lainnya dijelaskan oleh variabel lain yang tidak diteliti dalam penelitian ini. Nilai $\mathrm{p}$ atau signifikansi dapat digunakan untuk menguji hipotesis penelitian. Nilai $\mathrm{p}<0,05$ menandakan bahwa hipotesis nol ditolak dan hipotesis alternatif diterima (Pallant, 2011). Oleh karena itu, hipotesis kerja, yaitu bahwa terdapat pengaruh modal psikologis terhadap persepsi resiliensi organisasi dalam pandemi COVID-19, diterima.

Selanjutnya, dapat disimpulkan bahwa variabel modal psikologis $(\mathrm{B}=0,391, \mathrm{CI} 95=[0,331 ; 0,450], \mathrm{SE}=$ $0,578, t=12,88$, nilai $\mathrm{p}<0,001$ ) berkorelasi positif dan kuat dalam menjelaskan persepsi resiliensi organisasi.

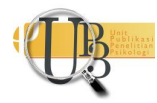




\section{I S K U S I}

Berdasarkan hasil analisis regresi linear sederhana, variabel modal psikologis memiliki pengaruh yang signifikan terhadap variabel persepsi resiliensi organisasi $(p<0,001, S E=57,8 \%)$. Hal ini mendukung penelitian sebelumnya yang dilakukan oleh Fang dkk. (2020) yang menyatakan bahwa resiliensi organisasi dapat dibangun melalui modal psikologis manajer perusahaan kecil di Selandia Baru dalam menghadapi dampak yang disebabkan oleh gempa bumi. Selanjutnya, Fang dkk. (2020) menjelaskan bahwa pengaruh yang diberikan oleh modal psikologis terhadap resiliensi organisasi diaktivasikan oleh problem focused dan emotion focused coping strategies. Kemudian, Fang dkk. (2020) menambahkan bahwa kombinasi antara ketiga variabel tersebut akan meningkatkan kesadaran terhadap situasi, jaringan sosial yang lebih baik, dan pengambilan keputusan yang cepat, yang mana hal-hal tersebut merupakan indikator dari sebuah organisasi yang resilien (Lee dkk., 2013; McManus, 2008; Stephenson, 2010).

Bagaimana masing-masing komponen dari modal psikologis dapat mempengaruhi resiliensi organisasi juga dijelaskan dalam penelitian Fang dkk. (2020). Penelitian sebelumnya menunjukkan bahwa tingkat self-efficacy dapat memberikan pengaruh yang positif terhadap tindakan pencegahan dan pengelolaan kedaruratan (Kim dkk., 2012 dalam Fang dkk., 2020). Selain itu, self-efficacy mempengaruhi tingkat stres pascabencana (Benight \& Harper, 2002 dalam Fang dkk., 2020). Selanjutnya, individu yang memiliki self-efficacy yang tinggi cenderung mampu untuk menemukan solusi yang kreatif dan inovatif untuk menghadapi suatu masalah (Ahlin, Drnovsek, \& Hisrich, 2014 dalam Fang dkk., 2020), yang mana kreativitas dan inovasi merupakan salah satu indikator dari kapasitas adaptif, yang merupakan salah satu dimensi resiliensi organisasi. Hal ini terjadi karena individu yang memiliki self-efficacy yang tinggi mampu mengetahui kemampuannya dalam mengerjakan suatu tugas tertentu, dan memiliki keyakinan terhadap kemampuannya untuk menyelesaikan tugas tersebut (Fang, Prayag, Ozanne, \& de Vries, 2020). Tingkat self-efficacy juga bisa mempengaruhi bagaimana individu di dalam organisasi mampu bangkit dan menerima perubahan dari kenyataan yang ada, lalu menetapkan arah tujuan yang baru untuk menghadapi krisis (Paglis \& Green, 2002 dalam Fang, Prayag, Ozanne, \& de Vries, 2020).

Selanjutnya, dimensi harapan juga ditemukan dapat memberikan kemampuan bagi individu untuk berinovasi dan berkreasi (Fang, Prayag, Ozanne, \& de Vries, 2020). Terdapat tiga komponen pada dimensi harapan, yaitu goals, pathway thinking, dan agency thinking. Goals, atau tujuan, merupakan komponen kognitif dari harapan, yang memberikan arahan mengenai tujuan yang ingin dicapai oleh individu. Sementara, pathway thinking adalah bagaimana cara untuk mencapai tujuan, sedangkan agency thinking adalah kegigihan untuk mencapai tujuan, yang merupakan komponen motivasional dari harapan (Snyder, 2002 dalam Fang dkk., 2020). Ketiga komponen dari dimensi harapan tersebut, seperti dimensi self-efficacy memberikan kemampuan bagi individu untuk berkreasi dan berinovasi. Hal tersebut terjadi sebagai dampak dari way power atau pathway thinking individu (Fang, Prayag, Ozanne, \& de Vries, 2020). Selanjutnya, Fang dkk. (2020) menjelaskan bahwa way power tersebut ditunjukkan melalui kemampuannya untuk mencari jalan alternatif untuk memecahkan masalah. Secara sederhana, goal merupakan premis dari harapan, sementara way power dan will power menunjukkan pathway dan agency thinking (Fang, Prayag, Ozanne, \& de Vries, 2020). Individu yang penuh akan harapan menghadapi masalah dengan menetapkan tujuan yang jelas, lalu menganggap rintangan sebagai tantangan, dan berfokus pada keberhasilan (Rodriguez-Hanley \& Snyder, 2000 dalam Fang dkk., 2020). Dapat disimpulkan bahwa dimensi hope mempengaruhi resiliensi organisasi melalui will power dan way power, yang menyebabkan individu menjadi kreatif dan inovatif.

Individu yang optimis menginterpretasi suatu kejadian yang negatif sebagai sesuatu yang bersifat sementara dan merupakan sesuatu yang diluar kendalinya (Luthans \& Youssef, 2007). Individu yang

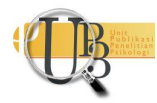


optimis, misalnya, menganggap bahwa suatu bencana alam merupakan hal yang tidak bisa dikendalikan olehnya. Karenanya, dia akan bergerak maju dari bencana tersebut, dan berusaha melihat sisi positif dari kejadian tersebut (Fang, Prayag, Ozanne, \& de Vries, 2020). Individu yang optimis menggunakan positive thinking dan rational thinking untuk menghadapi dan menjelaskan situasi yang buruk yang terjadi padanya (Fang, Prayag, Ozanne, \& de Vries, 2020). Selain itu, individu yang optimis melihat situasi yang buruk sebagai suatu kesempatan, bukan sebagai alasan untuk menyerah (Fang, Prayag, Ozanne, \& de Vries, 2020). Namun, perlu dicatat bahwa optimisme yang ditunjukkan haruslah realistis. Optimisme yang tidak realistis dapat menimbulkan harapan yang palsu dan kekecewaan yang tinggi apabila suatu kejadian tidak sesuai dengan ekspektasi individu (Shepperd dkk., 2015 dalam Fang dkk., 2020). Optimisme yang realistis, sebaliknya, dapat menghindarkan individu dari ekspektasi yang tidak realistis, dan menghindarkan individu dari kekecewaan apabila ekspektasi tersebut tidak tercapai (Shepperd dkk., 2015 dalam Fang dkk., 2020). Individu yang optimis, menurut Fang dkk. (2020), sadar bahwa situasi yang dihadapinya tidak pasti. Hal ini menjadikan individu tersebut menampilkan kesadaran situasi yang baik, dengan menunjukkan kewaspadaan terhadap lingkungan internal dan eksternal dari organisasi. Hal ini sejalan dengan salah satu komponen penting dari resiliensi organisasi, yaitu kesadaran terhadap situasi (Stephenson, 2010; McManus, 2008). Dapat disimpulkan bahwa individu yang optimis dapat meningkatkan resiliensi organisasinya melalui peningkatan pada kapasitas kesadaran terhadap situasi (Fang, Prayag, Ozanne, \& de Vries, 2020).

Selanjutnya, dimensi resiliensi psikologis memberikan pengaruhnya dengan menjadikan individu untuk mampu menggunakan pendekatan firefighting dalam memecahkan masalah, artinya, individu menghasilkan rencana-rencana darurat yang langsung menyesuaikan terhadap situasi, dan menjadi adaptif ketika sedang menghadapi perubahan (Ates \& Bititci, 2018 dalam Fang dkk., 2020). Selain itu, individu yang resilien cenderung menggunakan referensi sosial dan dukungan sosial dari keluarga, teman, dan rekan kerja sebagai mekanisme coping untuk memfasilitasi tujuan personal atau bisnis (Fang, Prayag, Ozanne, \& de Vries, 2020). Jaringan sosial tersebut merupakan salah satu faktor yang mempengaruhi resiliensi organisasi (Stephenson, 2010; McManus, 2008), dan individu yang berhasil membangun jaringan sosial dan kerja sama bisnis dapat berkontribusi terhadap resiliensi organisasi (Fang, Prayag, Ozanne, \& de Vries, 2020). Namun, menurut Fang dkk. (2020) ketergantungan pada resiliensi yang berlebihan dapat mengindikasikan perencanaan yang buruk, sehingga baiknya strategi yang bersifat adaptif diseimbangkan dengan perencanaan yang baik.

\section{S I M P U L A N}

Berdasarkan hasil serangkaian analisis dan pembahasan yang dilakukan oleh penulis, dapat disimpulkan bahwa hipotesis alternatif ( $\mathrm{Ha}$ ) diterima, artinya bahwa terdapat pengaruh yang signifikan dari variabel modal psikologis terhadap variabel persepsi resiliensi organisasi pada level individu. Saran untuk penelitian selanjutnya adalah untuk menspesifikkan organisasi atau perusahaan yang akan diteliti. Hal ini untuk memungkinkan untuk mengetahui pengaruh modal psikologis terhadap resiliensi organisasi dalam level organisasi, yang juga bisa mengembangkan hasil temuan penelitian ini.

\section{U C A P A N T E R I MAKASIH}

Penulis berterima kasih kepada para partisipan yang sudah mengisi kuesioner penelitian ini dan membantu penulis dalam mengumpulkan data. Penulis juga ingin mengucapkan terima kasih kepada semua pihak yang sudah membantu penulis untuk menyelesaikan penelitian ini, yang sayangnya tidak bisa disebutkan satu per satu.

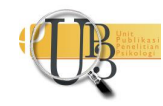




\section{DEKLARASI POTENSI TERJADINYA KONFLIK KEPENTINGAN}

Muhammad Farras Said dan Dimas Aryo Wicaksono tidak bekerja, menjadi konsultan, memiliki saham, atau menerima dana dari perusahaan atau organisasi manapun yang mungkin akan mengambil untung dari diterbitkannya naskah ini.

\section{PUST AKA ACUAN}

CNN Indonesia. (2020, Mei 11). Sri Mulyani Sebut Kebijakan PSBB 'Pukul' Ekonomi RI. Dipetik September 3, 2020, dari CNN Indonesia: https://www.cnnindonesia.com/ekonomi/20200511132615532-502066/sri-mulyani-sebut-kebijakan-psbb-pukul-ekonomi-ri

Fang, S. E., Prayag, G., Ozanne, L. K., \& de Vries, H. (2020). Psychological capital, coping mechanisms and organizational resilience: Insights from the 2016 Kaikoura earthquake, New Zealand. Tourism Management Perspective.

Gibson, C. A., \& Tarrant, M. (2010). A 'Conceptual Models' Approach to Organisational Resilience. Australian Journal of Emergency Management, 1324-1540.

Harms, P., Brady, L., Wood, D., \& Silard, A. (2018). Resilience and Well-Being. Handbook of well-being, 112.

Lee, A. V., Vargo, J., \& Seville, E. (2013). Developing a Tool to Measure and Compare Organizations' Resilience. Natural Hazards Review, 29-41.

Luthans, F., Youssef, C. M., \& Avolio, B. J. (2007). Psychological Capital: Developing the Human Competitive Edge. New York: Oxford University Press.

Mallak, L. A. (1998). Measuring resilience in health care provider. Health Manpower Management, 24(4), 148-152.

McManus, S. T. (2008). Organisational Resilience in New Zealand.

Navarro, D. J., \& Foxcroft, D. R. (2019). Learning Statistics with Jamovi: A Tutorial for Psychology Students and Other Beginners. (Version 0.70). doi:10.24384/hgc3-7p15

Neuman, W. L. (2014). Social Research Methods: Qualitative and Quantitative Approaches (7th ed.). Pearson Education Limited.

Pallant, J. (2011). SPSS survival manual: A step by step guide to data analysis using SPSS for windows (3rd Ed.). Berkshire: Open University Press.

Purwasono, G. R. (2016). HUBUNGAN ANTARA PSYCHOLOGICAL CAPITAL DENGAN WORK ENGAGEMENT PADA KARYAWAN GENERASI Y DI PT. SEMEN INDONESIA (PERSERO) TBK. Surabaya.

Shani, O. (2020). Organizational Resilience: Antecedents, Consequences, and Practical Implications - for Managers and Change Leaders . Research in Organizational Change and Development, 127-158.




Somers, S. (2009). Measuring Resilience Potential: An Adaptive Strategy for Organizational Crisis Planning. Journal of Contigencies and Crisis Management, 12-23.

Stephenson, A. V. (2010). Benchmarking The Resilience of Organization.

Thomas, V. F. (2020, Agustus 5). Pertumbuhan Ekonomi RI Q2 2020 Minus 5,32\%, Terburuk Sejak 1999. (N. Q. Pramisti, Editor) Dipetik September 3, 2020, dari tirto.id: https://tirto.id/pertumbuhanekonomi-ri-q2-2020-minus-532-terburuk-sejak-1999-fVQK

Tim Komunikasi Publik Satuan Tugas Penanganan COVID-19. (2020, Agustus 18). Masker Menjadi Peluang Usaha di Masa Pandemi COVID-19. Diambil kembali dari https://covid19.go.id/p/berita/masker-menjadi-peluang-usaha-di-masa-pandemi-covid-19

Whitman, Z. R., Kachali, H., Roger, D., Vargo, J., \& Seville, E. (2013). Short-form version of the Benchmark Resilience Tool (BRT-53). Measuring Business Excellence, 17(3), 3-14.

World Health Organization. (2020, April 17). Q\&A on coronaviruses (COVID-19). Dipetik Oktober 13, 2020, dari World Health Organization: https://www.who.int/emergencies/diseases/novelcoronavirus-2019/question-and-answers-hub/q-a-detail/q-a-coronaviruses

World Health Organization. (2020, Juli 9). Transmission of SARS-CoV-2: implications for infection prevention precautions: scientific brief, 09 July 2020. Geneva, Swiss: World Health Organization.

World Health Organization. (2020, Maret 11). WHO Director-General's opening remarks at the media briefing in COVID-19 - 11 March 2020. Diambil kembali dari World Health Organization: https://www.who.int/director-general/speeches/detail/who-director-general-s-openingremarks-at-the-media-briefing-on-covid-19---11-march-2020

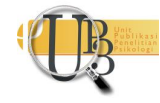

